\title{
A Study on Dental Hygiene and Career Maturity of Students Based on Alderfer's ERG Theory
}

\author{
Yang-Keum $\mathrm{Han}^{1}$ and An-Na Yeo ${ }^{2, \dagger}$ \\ 'Department of Dental Hygiene, Daejeon Health Institute of Technology, Daejeon 34504, ${ }^{2}$ Department of Dental \\ Hygiene, Daejeon Institute of Science and Technology, Daejeon 35408, Korea
}

\begin{abstract}
Background: This study aimed to investigate the effects of department satisfaction and career maturity on the perceived health status, relationship, and self-efficacy of dental hygiene college students based on Alderfer's existence-relationship-growth theory.

Methods: We obtained convenience samples of dental hygiene students in Daejeon and Chungnam areas; 241 questionnaires were collected from 250 persons considering the dropout rate and used for the final analysis except for 9 careless responses. The differences in perceived health status, relationship, self-efficacy, department satisfaction, and career maturity according to general characteristics were analyzed using a t-test, one-way analysis of variance and Pearson's correlation coefficients. Moreover, structural equation modeling was performed to confirm the variables. GFI, AGFI, CFI, RMR, RMSEA, TLI, and NFI indices were calculated to verify the fitness of the path model.

Results: There were significant differences in self-efficacy, department satisfaction, career maturity according to grade, and significant differences in academic performance for all variables except relationship. The school system also had a significant effect on department satisfaction. Perceived health status, relationship, self-efficacy, department satisfaction, and career maturity demonstrated statistically significant positive correlations $(p<0.05)$. The factors affecting department satisfaction were relationship and self-efficacy. The indirect and total effects of perceived health status and relationship on career maturity were not statistically significant; however, the indirect and total effects of self-efficacy on career maturity were statistically significant. Conclusion: It is necessary to develop teaching methods according to student management plans for dental hygiene by comprehensively perceived health status, relationship, and self-efficacy affecting department satisfaction and career maturity.
\end{abstract}

Key Words: Dental hygienists, Health status, Self efficacy, Structural equation modelings

\section{Introduction}

University life is an important time to make career decisions, and most university students in Korea are contemplating their careers after enrollment and are striving to acquire the necessary qualities as a professional ${ }^{1}$. University majors can be seen as a preparatory stage for effective job performance and adaptation in the workplace after employment ${ }^{2}$. If the current majoring department matches the criteria for one's ideal, career, and job, the degree of satisfaction with the major increases ${ }^{3)}$.
Dental hygiene students are given a license to become dental hygienist from the Ministry of Health and Welfare after passing the national examination conducted by the Korea Health Personnel Licensing Examination Institute. The basic motivation for joining majors is the professionalism and job stability after graduation, and most career paths are determined at the same time simultaneously as they go to university ${ }^{4}$.

Dental hygienists perform various roles while providing dental treatment ${ }^{5}$. Not only do they provide high-quality dental services, but also develop sufficient trust through 
the relationship between patients and guardians, and physical health problems due to various factors when performing their duties ${ }^{6,7)}$; therefore, measures for health promotion are needed. Dental hygiene students must have professional knowledge and practice for effective work performance in the department, as well as physical health, cooperation and smooth interpersonal relationships, and a sense of mission and self-efficacy for work ${ }^{8)}$. Therefore, academic and department satisfaction is critical ${ }^{9)}$. Career maturity is the degree of preparation in career choice or planning ${ }^{10)}$. Depending on the current department satisfaction, interest and ability for the future will occur, along with specific planning for the career. Therefore, career maturity can only be achieved when satisfied with the department ${ }^{11)}$.

Previous research on department satisfaction and career maturity for dental hygiene students, reported that aptitude, school facility satisfaction, interpersonal relationship ability, admission motivation, self-esteem, and $\operatorname{sex}{ }^{12)}$. Other research has shown that both clinical practice stress according to sense of coherence and department satisfaction according to clinical practice stress had a negative influence, while department satisfaction according to sense of coherence had a positive influence ${ }^{13}$. The factors that influence department satisfaction were aptitude, school facility satisfaction, interpersonal relationship ability, admission motivation, self-esteem, and gender ${ }^{14)}$. The sub-factors were career attitude maturity, readiness, confidence, determinism, purpose, and independence ${ }^{15)}$. The main variables of career attitude maturity that influenced self-efficacy were career independence, readiness, and confidence $^{16)}$.

This study was based on Alderfer's ERG theory, which is a representative motivation theory, as variables affecting department satisfaction and career maturity. Motivation is generally a process of inducing and sustaining goaloriented behavior, and performance is the result of motivation; therefore, one must observe motivation to evaluate performance ${ }^{17)}$.

Most of the previous studies on department satisfaction and career maturity were conducted or correlated with the relationship between each variable rather than comprehensively dealing with each factor. This study aimed contribute to the development of teaching methods according to student management plans of dental hygienists majoring in comprehensively perceived health status, relationship, and self-efficacy by ERG theory as factors affecting department satisfaction and career maturity using structural equations.

\section{Materials and Methods}

\section{Participants}

This study was investigated after the consent of the participants in accordance with the approval of institutional review board. Dental hygiene students in the Daejeon and Chungnam areas were selected to explain the purpose and method of this study and to respond to the structuralself-report questionnaire from September 1 to November 7,2020 . The participants were selected using the $\mathrm{G}^{*}$ power 3.1.9.2 program to set a one-way ANOVA, significance level $=0.05$, effect size $=0.25$, and power $=0.8$. Consequently, the minimum number of participants was 180 , and 241 questionnaires were collected from 250 respondents, considering the dropout rate, and used for the final analysis, except for 9 careless responses.

\section{Study tools}

Existence needs, such as health and safety, are necessary for human beings' survival ${ }^{17)}$. In previous studies that applied the ERG theory, the more the participants perceived that they were physically healthy, the variable corresponding to the need for existence, the more the positive effect on the outcome ${ }^{18)}$. Therefore, the scale of existence needs was set as the perceived health status, and the level increased with increase in score.

Relationship needs are the desire to establish human relations with others as a social being, and the desire for interpersonal relations, affection, belonging, and respect are among the desired classes ${ }^{19)}$. The relationship scale consists of questions that indicate the connection between oneself and the world. Since intimacy, empathy, and affinity are constituent factors, they are highly correlated with the concept of relationship desire; therefore, this scale was used ${ }^{20)}$.

Finally, growth needs are related to personal growth 
efforts, which are related to personal confidence and selffulfillment ${ }^{17}$. The growth needs scale used self-efficacy of the concept of mediating individual behavior changes as an important variable that can obtain motivation effect for individuals as an important factor that affects human behavior and achievement level ${ }^{21)}$.

\section{1) Perceived health status}

The perceived health status scale was used by Choi and Sung ${ }^{22}$, which was modified and supplemented by the Health Perception Questionnaire developed by John E. Ware. The tool consists of 10 questions and is measured using a Likert 5-point scale. The higher the score, the higher the health perception. In the study by Choi and Sung ${ }^{22)}$, Cronbach's alpha was 0.69 , while it was 0.66 in this study.

\section{2) Relationship}

The relationship scale was developed by Kim and consisted of 15 questions that were completed by Jeon ${ }^{20)}$, which was measured using a Likert 5-point scale, higher score indicated higher relationship. In the study by Jeon ${ }^{20)}$, Cronbach's alpha was 0.748 , while it was 0.753 in this study.

\section{3) Self-efficacy}

The Self-efficacy scale was developed by $\mathrm{Kim}^{23}$, and Jeon $^{20)}$ completed the manual. It consisted of a total of 7 questions, it were measured using a Likert 5-point scale. The higher the score, the higher the self-efficacy. In the study of Jeon ${ }^{20)}$, Cronbach's alpha was 0.730 , while it was 0.803 in this study.

\section{4) Department satisfaction}

The study used a questionnaire similar to that in the study by $\mathrm{Kim}$ and $\mathrm{Ha}^{24)}$, which was modified and supplemented by Park ${ }^{25}$, and consisted of 20 questions. The score was measured using a Likert 5-point scale and the higher the score, the higher the degree of satisfaction. In the previous study, Cronbach's $\alpha$ was 0.939 while it was 0.952 in this study.

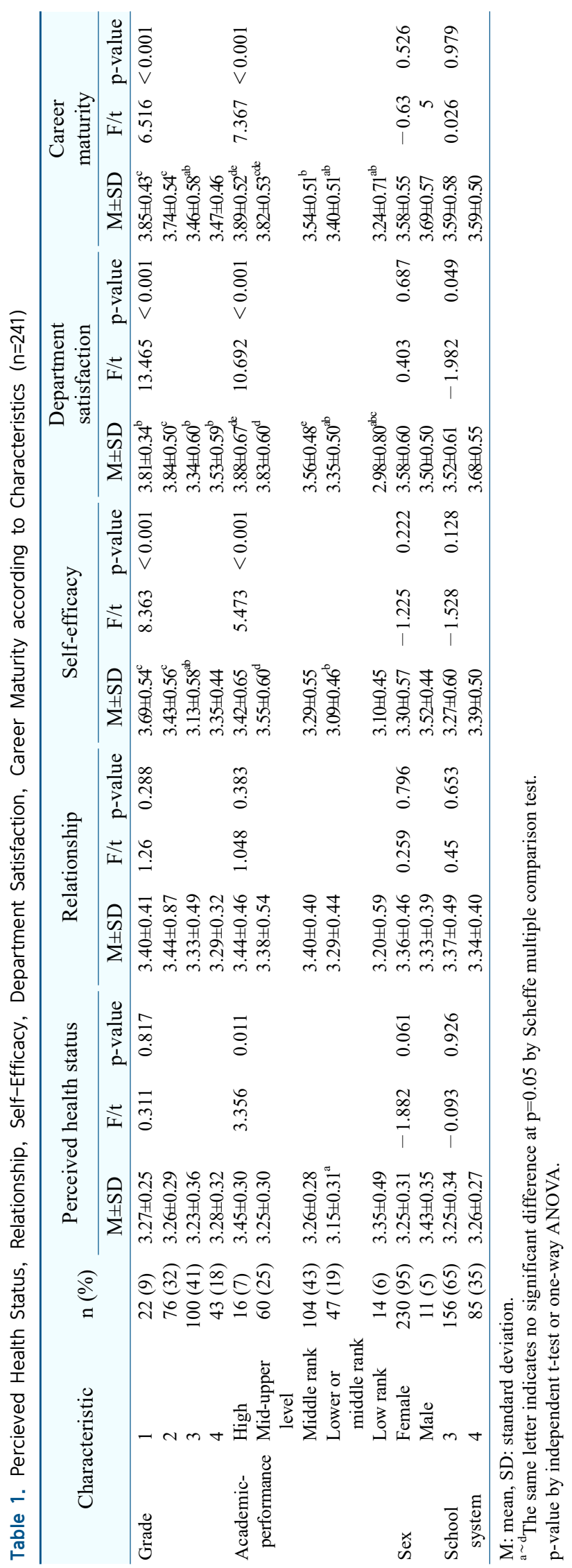




\section{5) Career maturity}

Career maturity is a tool for determining career maturity of the Korean Youth Index Survey by the Korea Youth Policy Institute ${ }^{26)}$; however, Joo and $\mathrm{Kim}^{27)}$ secured reliability and validity by complementing the appropriateness and internal consistency of the questions. It consists of 10 questions and is a score measured using a Likert 5-point scale. In the previous study, Cronbach's $=0.77$ was observed, while it was 0.859 in this study.

\section{Data analysis}

The general characteristics were analyzed using descriptive statistics and frequency, and the differences in perceived health status, relationship, self-efficacy, department satisfaction, and career maturity according to general characteristics were analyzed using t-test and one-way ANOVA. Pearson's correlation coefficients was used to verify the correlation.

Structural equation modeling was used to confirm the causal relationship between perceived health status, relationship, self-efficacy, department satisfaction, and career maturity. Goodness-of-fit index (GFI), comparative fit index (CFI), root mean-squared residual (RMR), normed fit index (NFI), adjusted GFI (AGFI), TuckerLewis index (TLI), and root mean square error of approximation (RMSEA) were calculated to verify the fitness of the path model. The collected data were analyzed using IBM SPSS 20.0 (IBM Co., Armonk, NY, USA) and AMOS 23.0 (IBM CO., Chicago, IL, USA), and statistical analysis was performed with a significance level of 0.05 .

\section{Results}

1. Differences in perceived health status, relationship, self-efficacy, department satisfaction, and career maturity according to general characteristics

Differences in perceived health status, relationship, self-efficacy, department satisfaction, and career maturity according to general characteristics are shown in Table 1. In terms of self-efficacy and career maturity according to grade, there was a significant difference between the third, fourth, and first graders, and higher in the first grade $(\mathrm{p}<$ $0.001)$. Department satisfaction was significantly different between the first and third grades, and higher in the first and second grades $(p<0.001)$. There were significant differences in perceived health status, self-efficacy, department satisfaction, and career maturity according to grade $(p<0.05)$. Regarding perceived health status, high-ranked students had higher status than that among middle-lower students, and regarding self-efficacy, middlehigh ranked students had higher self-efficacy than that among middle-lower students. In terms of department satisfaction, high and middle-high students had higher satisfaction than that among lower-level students, while high-ranked students had higher career maturity than that among lower-level students. In the school system standard, the satisfaction of the 'four-year' students was $3.68 \pm 0.55$, which was statistically significant $(\mathrm{p}<0.05)$.

\section{Correlation between perceived health status, relationship, self-efficacy, department satisfaction, and career maturity \\ Perceived health status, relationship, self-efficacy,}

Table 2. Correlations between Perceived Health Status, Relationship, Self-Efficacy, Department Satisfaction, and Career Maturity

\begin{tabular}{|c|c|c|c|c|c|}
\hline Variable & $\begin{array}{l}\text { Perceived health } \\
\text { status }\end{array}$ & Relationship & Self-efficacy & $\begin{array}{l}\text { Department } \\
\text { satisfaction }\end{array}$ & Career maturity \\
\hline Perceived health status & 1 & & & & \\
\hline Relationship & $0.498 * *$ & 1 & & & \\
\hline Self-efficacy & $0.461 * *$ & $0.550 * * *$ & 1 & & \\
\hline Department satisfaction & $0.252 * *$ & $0.231 * * *$ & $0.381 * * *$ & 1 & \\
\hline Career maturity & $0.264 * * *$ & $0.383 * * *$ & $0.473 * * *$ & $0.883 * * *$ & 1 \\
\hline
\end{tabular}

$* * \mathrm{p}<0.01, * * * \mathrm{p}<0.001$ by pearson's correlation analysis. 
department satisfaction, and career maturity all showed statistically significant positive correlations $(p<0.05)$. The correlation between department satisfaction and career maturity was the highest $(\mathrm{r}=0.883$, Table 2$)$.

\section{Path model fit verification}

The results of the test were verified using GFI, AGFI,
CFI, root mean-squared residual (RMR), RMSEA, TLI, and NFI by entering the perceived health status, relationship, self-efficacy, department satisfaction, and career maturity to check the model fit (Table 3). $\chi^{2}=288.125$ was significant $(\mathrm{p}<0.001)$; however, the model was modified as both the absolute and incremental fit indices did not meet the standard value (Table 3). To

Table 3. Model Fit

\begin{tabular}{|c|c|c|c|c|c|c|c|c|}
\hline Model fit & $\chi^{2}$ & GFI & AGFI & CFI & RMR & RMSEA & TLI & NFI \\
\hline $\begin{array}{l}\text { Interpretation } \\
\text { standard }\end{array}$ & $\mathrm{p}<0.05$ & $\geq 0.9$ & $\geq 0.9$ & $\geq 0.9$ & $\leq 0.05$ & $\begin{array}{l}<0.10(\text { Normal }) \\
<0.08(\text { Good }) \\
\leq 0.05 \text { (Adequate })\end{array}$ & $\geq 0.9$ & $\geq 0.9$ \\
\hline $\begin{array}{l}\text { Before } \\
\text { modification }\end{array}$ & $288.125(\mathrm{p}<0.001)$ & 0.877 & 0.831 & 0.881 & 0.042 & 0.081 & 0.794 & 0.755 \\
\hline $\begin{array}{l}\text { After } \\
\text { modification }\end{array}$ & $218.690(\mathrm{p}<0.001)$ & 0.904 & 0.901 & 0.902 & 0.034 & 0.066 & 0.896 & 0.890 \\
\hline
\end{tabular}

GFI: goodness-of-fit index, AGFI: adjusted GFI, CFI: comparative fit index, RMR: root mean-squared residual, RMSEA: root mean square error of approximation, TLI: Turker-Lewis index, NFI: normal fit index.

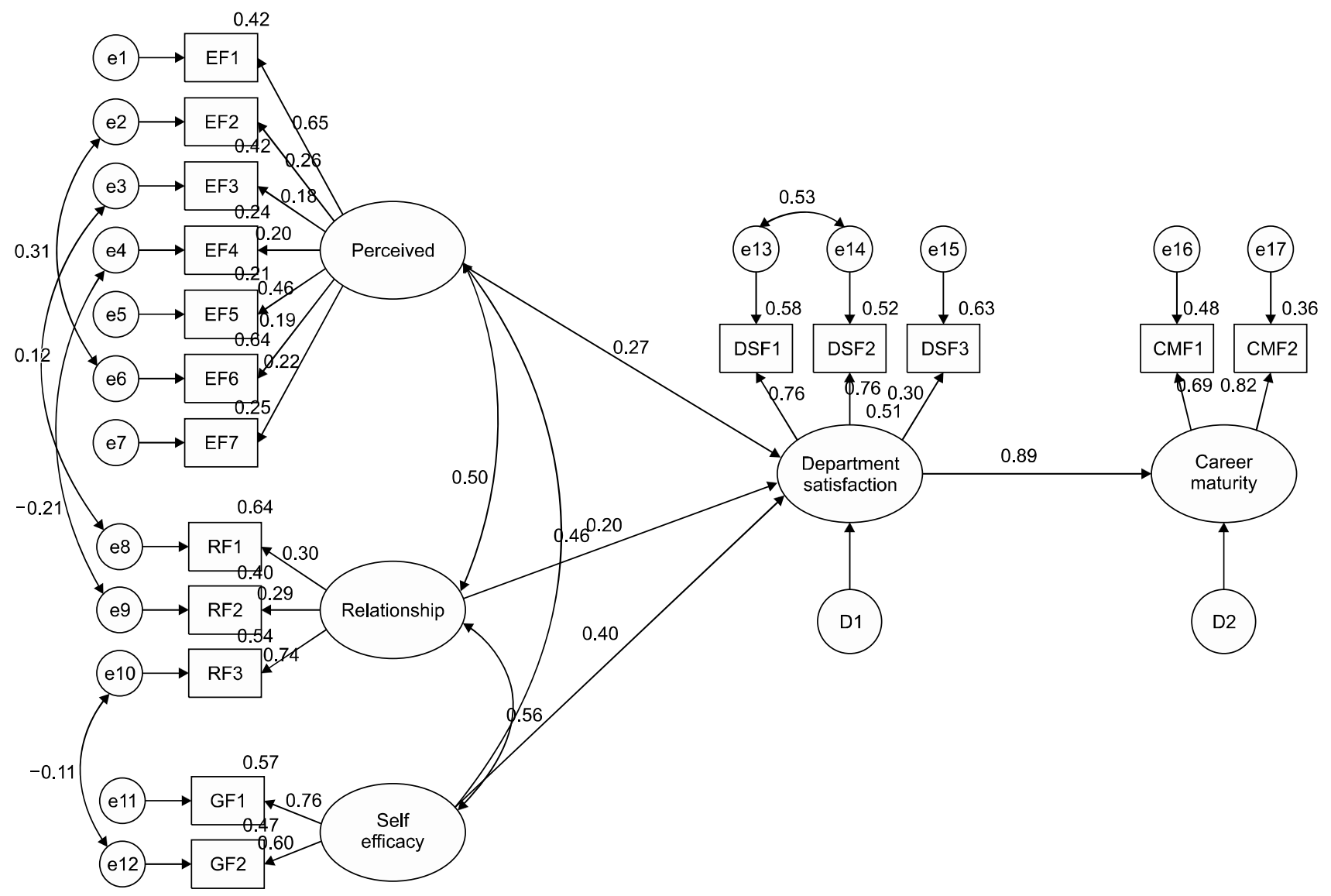

Fig. 1. Structural model based on estimation of standardized path coefficient. EF: existence need factor, RF: relationship need factor, GF: growth need factor, DSF: department satisfaction factor, CMF: career maturity factor. 
increase the model fit, the model was modified by setting the path between error terms that were theoretically judged to be valid among the modified indices analyzed ${ }^{28)}$. The error terms were set up as perceived health status $2 \leftrightarrow$ perceived health status 6 (modified indices $[\mathrm{MI}]=19.801$, par charge $=0.169$ ), perceived health status $3 \leftrightarrow$ relationship $1 \quad(\mathrm{MI}=4.629$, par charge $=0.041)$, perceived health status $4 \leftrightarrow$ relationship $2(\mathrm{MI}=9.906$, par charge $=-0.059)$, relationship $3 \leftrightarrow$ self-efficacy 2 (MI=4.209, par charge= $-0.059)$, and department satisfaction $1 \leftrightarrow$ department satisfaction $2(\mathrm{MI}=4.716$, par charge $=0.018)$, and the model was modified (Fig. 1). The results of the modification were $\chi^{2}=218.690(p<0.001)$, and most of the fit indices improved.

\section{Model path coefficients and effect analysis}

The results of the path analysis are shown in Table 4 and Fig. 1. The factors affecting department satisfaction were relationship $(\beta=0.199$, critical ratio $[\mathrm{CR}]=2.0178, \mathrm{p}<$ $0.05)$ and self-efficacy $(\beta=0.399, C R=3.620, p<0.001)$. The square multiple correlations of the model was $52 \%$, department satisfaction according to relationship and self-efficacy showed a positive $(+)$ effect, and the higher the relationship and self-efficacy, the higher the department satisfaction. Career maturity $(\beta=0.891, C R=8.631, p<$ 0.001 ) according to department satisfaction was statistically significant and had a positive $(+)$ effect, and the square multiple correlations were $79 \%$.

The results of analyzing the direct, indirect, and total effects among factors in the path model are shown in Table 5. To verify the significance of the indirect effect, a bootstrapping method was performed, and the significance level was confirmed by two-tailed significance (biascorrected). The direct effect of perceived health status on department satisfaction $(\beta=0.266, p=0.066)$ and the total effect were not statistically significant. The direct and total effects of relationship $(\beta=0.199, \mathrm{p}<0.05)$ and selfefficacy $(\beta=0.339, \mathrm{p}<0.001)$ on department satisfaction were statistically significant. The direct effect of department satisfaction on career maturity $(\beta=0.891, \mathrm{p}<$ 0.001 ) and the total effect were statistically significant. The indirect and total effects of perceived health status $(\beta=0.237, p=0.053)$ and relationship $(\beta=0.178, p=0.117)$ on career maturity were not statistically significant; however, the indirect and total effects of self-efficacy $(\beta=0.356, p<0.05)$ on career maturity were statistically significant.

Table 4. Model Path Coefficients

\begin{tabular}{|c|c|c|c|c|c|}
\hline \multirow{2}{*}{ Path } & \multicolumn{2}{|c|}{ Estimates } & \multirow{2}{*}{ SE } & \multirow{2}{*}{$\mathrm{CR}$} & \multirow{2}{*}{ SMC } \\
\hline & $\mathrm{B}$ & $\beta$ & & & \\
\hline Department satisfaction $\leftarrow$ Perceived health status & 0.521 & 0.266 & 0.283 & 1.979 & 0.522 \\
\hline Department satisfaction $\leftarrow$ Relationship & 0.169 & 0.199 & 0.088 & 2.018 & \\
\hline Department satisfaction $\leftarrow$ Self-efficacy & 0.372 & 0.399 & 0.103 & 3.620 & \\
\hline Career maturity $\leftarrow$ Department satisfaction & 0.871 & 0.891 & 0.100 & 8.631 & 0.794 \\
\hline
\end{tabular}

SE: standard error, CR: critical ratio, SMC: squared multiple correlation.

Table 5. Direct Effect, Indirect Effect, Total Effect of Variable

\begin{tabular}{|c|c|c|c|c|}
\hline Endogenous variable & Exogenous variable & $\begin{array}{c}\text { Direct effect } \\
\text { (p-value) }\end{array}$ & $\begin{array}{c}\text { Indirect effect } \\
\text { (p-value) }\end{array}$ & $\begin{array}{l}\text { Total effect } \\
\text { (p-value) }\end{array}$ \\
\hline \multirow[t]{3}{*}{ Department satisfaction } & $\leftarrow$ Perceived health status & $0.266(0.066)$ & & $0.266(0.066)$ \\
\hline & $\leftarrow$ Relationship & $0.199(<0.05)$ & & $0.199(<0.05)$ \\
\hline & $\leftarrow$ Self-efficacy & $0.399(<0.001)$ & & $0.399(<0.001)$ \\
\hline \multirow[t]{4}{*}{ Career maturity } & $\leftarrow$ Department satisfaction & $0.891(<0.001)$ & & $0.891(<0.001)$ \\
\hline & $\leftarrow$ Perceived health status & & $0.237(0.053)$ & $0.237(0.053)$ \\
\hline & $\leftarrow$ Relationship & & $0.178(0.117)$ & $0.178(0.117)$ \\
\hline & $\leftarrow$ Self-efficacy & & $0.356(<0.05)$ & $0.356(<0.05)$ \\
\hline
\end{tabular}




\section{Discussion}

This study was conducted to investigate the effects of perceived health status, relationship, and self-efficacy on department satisfaction and the effects of department satisfaction on the career maturity of dental hygienist college students based on Alderfer's ERG theory.

The differences in perceived health status, relationship, self-efficacy, department satisfaction, and career maturity according to general characteristics were analyzed. There was a significant difference according to grade, academic performance, and school system; however, there was no statistically significant difference according to sex. According to grade, the self-efficacy and career maturity of the first-grade students were the highest, and the satisfaction level of the department was the highest among the second-grade students. In the previous studies ${ }^{29)}$, the degree of satisfaction was the highest among second-grade students, which was the same as that in this study. However, in previous studies ${ }^{12,30)}$, the satisfaction of third graders was high, which was different from the results of this study. Dental hygiene students are under various factors of stress due to preparation for national examinations $^{31)}$. Additionally, as the grade increases, department satisfaction decreases due to the burden of taking up more majors and increasing practice ${ }^{32)}$. The career maturity was similar to that in the previous studies $^{33)}$, in which the first and second graders had higher maturity than that among the third and fourth graders; however, Yu and Yang ${ }^{11)}$ showed that career maturity was higher among fourth and first graders. The higher the grade before graduation, the greater the anxiety regarding problems related to employment. Job stress has a statistically significant negative correlation with career maturity ${ }^{34)}$. Self-efficacy refers to an individual's ability to perform a task to achieve results. In most cases, as the age or grade advances, the range that can be performed in the major field expands, and unlike the results of this study, previous studies have shown that the higher the grade, the higher the sense of self-efficacy ${ }^{35)}$. In a study comprising dental hygiene first-year students, self-efficacy was the most important factor affecting school life adaptation, and it was found to be above the middle level by five points and had a positive $(+)$ effect on school life adaptation. Dental hygiene students must have an ideal college life and increase their self-efficacy to become competent in a rapidly changing modern society. To acquire sufficient knowledge and skills in the field of study, instructors should actively support, instill confidence, and provide opportunities for frequent contact with volunteer activities, club activities, and related programs.

In terms of department satisfaction and career maturity, the students with the highest academic performance were statistically significant. In previous studies, the higher the academic performance, the higher the department satisfaction $^{13,35,36)}$ and career maturity ${ }^{11)}$, which was consistent with the results of this study. Interest in majors and adaptation to the department induces the activeness of learning, which is considered to have a positive effect on interpersonal relations.

The department satisfaction according to the school system was higher among the 'four-year' students than that among the 'three-year' students. In the study by Jung and Jang ${ }^{37)}$, the department satisfaction of the 'four-year' students' was high, which was consistent with the results of this study. However, in other previous studies ${ }^{13,38)}$, the department satisfaction of the 'three-year' students was higher, which did not match the study. In a survey of 50 colleges with a 'three-year' school system ${ }^{39)}$, an average of 119.8 credits from a minimum of 104 credits to a maximum of 144 credits for 3 years was considered. The average theoretical class time was 72.3 hours, and the practical class time was 55.6 hours. Additionally, it is considered that most of the curriculum focusing on national examinations is insufficient compared to colleges that are operated as a 'four-year' school system to produce a wide range of dental hygienists required by society.

As a result of model verification, relationship and self-efficacy were shown to be variables that directly affect department satisfaction. Lee et al.'s study ${ }^{14)}$ showed that interpersonal competence and department satisfaction were positively correlated and similar to this study as statistically significant results. Before working as a dental hygienist, it is deemed necessary to make efforts, such as participating in group counseling and communication programs, to improve interpersonal skills in the university 
education process.

Department satisfaction was found to be a significant variable that directly affects career maturity. A previous study $^{40)}$ showed a positive correlation with career maturity, and the higher the department satisfaction, the higher the career maturity, which was similar to the results of this study. Students with high department satisfaction can be considered to have high career maturity, indicating the degree of career choice or preparation in their plans.

Self-efficacy had indirect effects on career maturity through the mediation of department satisfaction. Previous studies ${ }^{16)}$ have shown that self-efficacy and career decisionmaking have a positive $(+)$ effect. The more students who think they have high job tasks and processing skills and are willing to cope with difficult situations, the faster they make decisions with confidence in determining their career paths. Additionally, self-efficacy has a strong ability to explain the deterministic dimension of career maturity, which is consistent with the results of this study. It is considered that universities should develop departments of dental hygiene and their career counseling programs, not comprehensive employment and career education; thus, can play an important role in mature career decisions based on department satisfaction by making a systematic portfolio of overall grades.

The limitations of this study are that it is difficult to generalize the results as the participants were selected from convenience sampling in limited areas. The number of 'four-year' students and male students was relatively small; therefore, it was difficult to accurately estimate the true picture of the population. It is suggested that studies on students majoring in dental hygiene are repeatedly conducted through random extraction to explore various factors that affect department satisfaction and career maturity, establish a path model, and identify a model with high explanatory power. Based on the results of this study, a variety of programs that can improve the department satisfaction and career maturity of students in dental hygiene should be developed and applied.

\section{Notes}

\section{Conflict of interest}

No potential conflict of interest relevant to this article was reported.

\section{Ethical approval}

This study was approved by the Institutional Review Board of Daejeon Health Institute of Technology (IRB No. 1041490-20200529-HR-003).

\section{Author contributions}

Conceptualization: YK Han, AN Yeo, Data acquisition: YK Han, AN Yeo, Formal analysis: AN Yeo, Funding: Daejeon Health of Technology, Supervision: YK Han, Writing-original draft: YK Han, AN Yeo, Writing-review \& editing: YK Han, AN Yeo.

\section{ORCID}

Yang-Keum Han, https://orcid.org/0000-0002-5074-0053

An-Na Yeo, https://orcid.org/0000-0003-2500-1408

\section{Acknowledgements}

This study was supported by research fund from Daejeon Health Institute of Technology, 2020.

\section{References}

1. Lim JH: Construction of a structural model about nursing students' academic motivation, ego-resilience, and satisfaction in major. JKDAS 16: 2273-3284, 2014.

2. Moon IO, Lee GW: The effect of satisfaction in major and career search efficacy on career search behavior in nursing students. J Korean Acad Soc Nurs Educ 16: 83-91, 2010. https://doi.org/10.5977/JKASNE.2010.16.1.083

3. Jeong HY, Park OL: A correlation analysis of the sense of value, self efficacy, major satisfaction level, and career maturity level of beauty care major college students. J Korea Soc Beauty Art 10: 35-49, 2009.

4. Jeon MJ, Choi MS, Park JS: A survey on dental hygiene students' senses of employment. J Korean Acad Dental Hyg Educ 9: 294-305, 2009.

5. Kim HH, Kim SJ: Impact of appearance satisfaction and 
body image on interpersonal relationship among dental hygiene students in some regions. J Korea Contents Assoc 13: 337-347, 2013.

https://doi.org/10.5392/JKCA.2013.13.12.337

6. Yoon MS, Choi MS: The analysis of the prevention against virus infection in dental hygienist at medical treatment. J Dent Hyg Sci 7: 101-106, 2007.

7. Nam KW, Ha MS: Analysis characteristic the using surface EMG of scaling working of the dental hygienist with upper body musculoskeletal pain. J Korean Phys Ther Sci 19: 1-6, 2012.

8. Kang HS, So MH: The effect of self-esteem, self-efficacy on the college life adjustments of dental hygiene students. J Korean Soc Sch Community Health Educ 20: 135-146, 2019. https://doi.org/10.35133/kssche.20191231.12

9. Song YS, Kwon SB, Ahn KS, Kim YN, Kim SH, Cha MJ: A study on the department satisfaction of the students majoring dental hygiene at K-college. KyungBok Coll 7: 297-316, 2003.

10. Gribbons WD, Lohnes PR: Relationships among measures of readiness for vocational planning. J Couns Psychol 11: 13-19, 1964. https://doi.org/10.1037/h0044801

11. Yu EY, Yang YJ: A study on the difference among college students' department satisfaction and career maturity and the influence on career stress. JDC 11: 557-568, 2013. https://doi.org/10.14400/JDPM.2013.11.12.557

12. Choi MH, Lee HJ: Relationship between interpersonal relationship ability, interpersonal relationship satisfaction, stress and department satisfaction of dental hygiene students. JCIT 10: 160-166, 2020. https://doi.org/10.22156/CS4SMB.2020.10.02.160

13. Jeon KH, Lim SR, Kim M: The structural relationship among sense of coherence, clinical practice stress, and departmental satisfaction of dental hygiene students. J Dent Hyg Sci 16: 323-330, 2016.

https://doi.org/10.17135/jdhs.2016.16.5.323

14. Lee JR, Kim HJ, Ko HJ: The effects of self-esteem, interpersonal relationship abilities on department satisfaction in the dental hygiene students. J Korean Soc Dent Hyg 14: 39-47, 2014. https://doi.org/10.13065/jksdh.2014.14.01.39

15. Jung GO, Choi GY: Effect of dental hygiene students' major flow experience on career attitude maturity. J Korea Contents Assoc 14: 281-287, 2014.

https://doi.org/10.5392/JKCA.2014.14.06.281

16. Jung EK: Effect of self-efficacy in dental hygiene students on the career maturity level. J Korea Acad-Ind Cooper Soc 15: 7231-7238, 2014

https://doi.org/10.5762/KAIS.2014.15.12.7231

17. Joo SH, Chun SY, Kim TG, et al.: Educational administration and management. 5th ed. Hakjisa, Seoul, pp.148-150, 2015.

18. Han HR, Lee JM: A study on the latent growth curve modeling of the adolescent's subjective happiness: focused on Alderfer's ERG theory. JFBL 36: 103-117, 2018. https://doi.org/10.7466/JKHMA.2018.36.1.103

19. Ryan RM, Deci EL: Self-determination theory and the facilitation of intrinsic motivation, social development, and well-being. Am Psychol 55: 68-78, 2000. https://doi.org/10.1037/0003-066X.55.1.68

20. Jeon SH: Validation of the Korean adolescent's basic psychological need scale. J Adolesc Welf 16: 31-64, 2014.

21. Bandura A, Schunk DH: Cultivating competence, self-efficacy, and intrinsic interest through proximal self-motivation. J Personal Soc Psychol 41: 586-598, 1981. https://doi.org/10.1037/0022-3514.41.3.586

22. Choi YJ, Sung YH: Psychological well-being, perceived health status, and health promoting behavior of clinical nurses. J Korean Acad Nurs Adm 19: 589-598, 2013. https://doi.org/10.11111/jkana.2013.19.5.589

23. Kim HG, Ahn BJ: The relationship between psycho-social intervening variables and deviant behaviors of adolescence. JOEC 10: 163-194, 2004.

24. Kim KH, Ha HS: A study of department satisfaction factors of undergraduate students. Korea J Couns 1: 7-20, 2000.

25. Park KS: Self-efficacy and the satisfaction on dental hygiene-majoring students. Unpublished master's thesis, Jeju National University, Jeju, 2015.

26. Choi IJ, Kim BH, Hwang MH, Heo EY, Cho JH: The youth indicators survey in Korea IV. National Youth Policy Institute, Sejong, pp.379-387, 2009.

27. Joo YJ, Kim DS: The structural relationship among economic stress, school belonging, career decision-making self-efficacy, career maturity, and school satisfaction in specialized vocational high schools. J Educ Stud 45: 73-95, 2014. 
28. Shin GG: Structural equation modeling (SEM) with Amos 23. Chungram Publisher, Seoul, pp.78-95, 2013.

29. Park JH, Song HJ, Lee BY: The influences of ethical propensity, self-esteem and clinical satisfaction on major satisfaction in dental hygiene students. JKCS 9: 261-269, 2018.

https://doi.org/10.15207/JKCS.2018.9.6.261

30. Kim DH, Cho JW: The effect of interpersonal relationship satisfaction and self-control on department satisfaction in dental hygiene students. J Korean Soc Dent Hyg 20: 515-523, 2020.

https://doi.org/10.13065/jksdh.20200047

31. Park IS, Kim HJ: Research on some of dental hygiene students' stress over the national examination. J Korean Soc Dent Hyg 13: 659-668, 2013.

https://doi.org/10.13065/iksdh.2013.13.4.659

32. Choi UJ, Yu SH: A research on the department satisfaction of department of dental technology students. J Technol Dent 34: 263-271, 2012. https://doi.org/10.14347/kadt.2012.34.3.263

33. Tak SH, Kim SH, Koo HR: A study on the relation of family strength, self-efficacy and career maturity of college students. J Korea Fam Res Manag Assoc 16: 53-65, 2012.

34. Choi MS, Jang YH, Yun HK: Effect of self-resilience and self-efficiency on the satisfaction with major in dental hygiene students. J Korean Soc Dent Hyg 14: 155-162, 2014. https://doi.org/10.13065/jksdh.2014.14.02.155

35. Kim SG, Koo YK, Jeong MA: Satisfaction with major and view of profession among dental hygiene students. J Korea Contents Assoc 12: 248-255, 2012. https://doi.org/10.5392/JKCA.2012.12.08.248

36. Kim MN, Heo YM, Kim HJ, Ahn YS: Effect of values on major satisfaction in dental hygiene students. J Korean Soc Dent Hyg 15: 81-89, 2015. https://doi.org/10.13065/jksdh.2015.15.01.81

37. Jung JA, Jang YJ: A study on attitude and satisfaction of the students in department of dental hygiene. J Korean Soc Dent Hyg 11: 649-657, 2011.

38. Moon SJ, Ku IY, Choi HY, Ka KH: Study of on- and off-campus clinical practice satisfaction and major satisfaction among dental hygiene students in some regions. J Korea Acad-Ind Cooper Soc 15: 6793-6803, 2014. https://doi.org/10.5762/KAIS.2014.15.11.6793

39. Yuk SH: A survey of curriculum in 3-year-course dental hygiene department: focusing on major subjects. Unpublished master's thesis, Chungnam National University, Daejeon, 2019.

40. Lee JH, Jang HJ: Influence of the major satisfaction and career maturity on job-seeking stress of nursing and public health university students. JKOCS 35: 454-462, 2018. https://doi.org/10.12925/jkocs.2018.35.2.454 